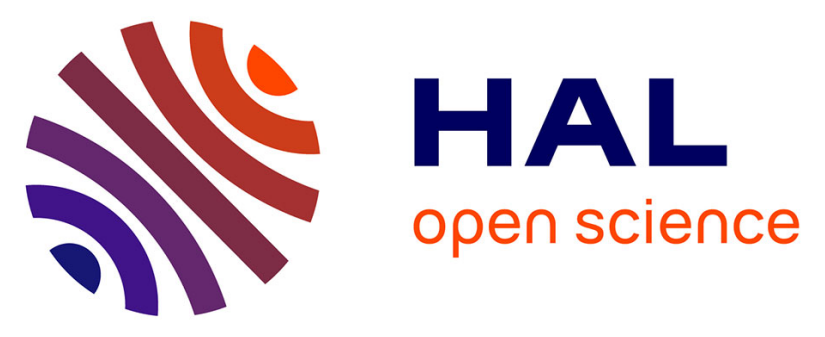

\title{
Characterization of Urea Biosensor Based on the Immobilization of Bacteria Proteus Mirabilis in Interaction with Iron Oxide Nanoparticles on Gold Electrode
}

\author{
Yosra Braham, Houcine Barhoumi, Abderrazak Maaref, Amina Bakhrouf, \\ Christine Grauby-Heywang, Touria Cohen-Bouhacina, Nicole Jaffrezic-Renault
}

\section{To cite this version:}

Yosra Braham, Houcine Barhoumi, Abderrazak Maaref, Amina Bakhrouf, Christine Grauby-Heywang, et al.. Characterization of Urea Biosensor Based on the Immobilization of Bacteria Proteus Mirabilis in Interaction with Iron Oxide Nanoparticles on Gold Electrode. Journal of Biosensors \& Bioelectronics, 2015, 6 (1), pp.1000160. 10.4172/2155-6210.1000160 . hal-01406863

\section{HAL Id: hal-01406863 https://hal.science/hal-01406863}

Submitted on 1 Dec 2016

HAL is a multi-disciplinary open access archive for the deposit and dissemination of scientific research documents, whether they are published or not. The documents may come from teaching and research institutions in France or abroad, or from public or private research centers.
L'archive ouverte pluridisciplinaire HAL, est destinée au dépôt et à la diffusion de documents scientifiques de niveau recherche, publiés ou non, émanant des établissements d'enseignement et de recherche français ou étrangers, des laboratoires publics ou privés. 


\title{
Characterization of Urea Biosensor Based on the Immobilization of Bacteria Proteus Mirabilis in Interaction with Iron Oxide Nanoparticles on Gold Electrode
}

Yosra Braham ${ }^{1 *}$, Houcine Barhoumi ${ }^{1}$, Abderrazak Maaref $^{1}$, Amina Bakhrouf $^{2}$, Christine Grauby Heywang ${ }^{3}$, Tauria Cohen Bouhacina ${ }^{3}$ and Nicole Jaffrezic-Renault ${ }^{4}$

${ }^{1}$ Laboratory of Interfaces and Advanced Materials (LIMA), University of Monastir 5000, Tunisia

${ }^{2}$ Laboratory of Analysis, Treatment and Valorization of Environment Pollutants and Products, Faculty of Pharmcia, University of Monastir 5000 Tunisia

${ }^{3}$ Laboratory of Waves and Aquitaine Matter CNRS, UMR, 5798, University of Bordeaux 1, 351, crs, Liberation, 33405, Talence, France

${ }^{4}$ Laboratory of Analytical Sciences, UMR CNRS 5180, University of Claude Bernard-Lyon1, Bâtiment Raulin, 69622 Villeurbanne Cedex, France

\begin{abstract}
In this work we describe a new urea biosensor, based on the immobilization of bacteria, Proteus mirabilis on gold electrode. To improve the stability of the bio-system, additional materials were used such as functionalized $\mathrm{Fe}_{3} \mathrm{O}_{4}$ nanoparticles (NPs), cationic (PAH), anionic (PSS) polyelectrolytes, Bovine Serum Albumin (BSA) and glutaraldehyde as a cross-linking agent. The electrochemical performances of the developed bacteria biosensor was evaluated using the electrochemical impedance spectroscopy (EIS) and cyclic voltammetry measurements. The adhesion of the bacteria cell on gold electrode was evaluated using contact angle measurements. The morphology of bacteria and its interaction with $\mathrm{Fe}_{3} \mathrm{O}_{4}$ nanoparticles were evaluated with the atomic force microscopy (AFM). As a result, a sensitive, stable and reproducible urea biosensor was developed.
\end{abstract}

Keywords: Proteus mirabilis; $\mathrm{Fe}_{3} \mathrm{O}_{4}$; $\mathrm{PAH}$ and PSS polyelectrolytes; Impedance spectroscopy; Gold electrodes; Bacterial adhesion; Atomic Force Microscopy

\section{Introduction}

Investigating in analytical chemistry is essential for developing new methods aiming at addressing various aspects of the biological, environmental, clinical, and applied sciences and at affording the tools for chemical analysis. For example, biosensors based on metal materials such as gold has been widely explored [1], as transducers and the microorganisms as bio-receptor, offer innovative solution. To enhance biosensors performances metal nanoparticles have attracted much attention and demonstrated a wide range of applications due to their desirable chemical-physical, electronic and optical properties. The use of nanoparticles is one of the most interesting approaches to improve the performances of biosensor [2-4]. Moreover, among nanoparticles $\mathrm{Fe}_{3} \mathrm{O}_{4}$ have been for instance considered as suitable for enzyme immobilization due to their super paramagnetic behavior and low toxicity [5,6]. In fact, $\mathrm{Fe}_{3} \mathrm{O}_{4}$ nanoparticles were used to urease immobilization for urea biosensor development [7]. As known, the determination of urea in body fluids is of great interest in biomedical analysis. A variety of biosensors based on urease have been developed for the selective determination of urea. In fact, urease can be synthesized by many organisms like plants, fungi, invertebrates and some bacteria as well as Proteus mirabilis. Among them, bacteria present a multitude of choice for the development of new enzymatic biosensors with low cost and natural optimization [8].

In this study a new enzymatic biosensor based on gold electrode functionalized with $\mathrm{Fe}_{3} \mathrm{O}_{4}$ and immobilized Proteus mirabilis. The adhesion and the morphology of the hydrophilic Proteus mirabilis to the hydrophobic Au-coated structure with PAH in presence of the $\mathrm{Fe}_{3} \mathrm{O}_{4}$ nanoparticles were investigated using contact angle and AFM measurements, respectively.

The electrochemical performances of the developed biosensor were attempted using impedance method in terms of detection limits, sensitivity, linear range and activity.

\section{Material and Methods}

\section{Chemical and biological materials}

Proteus mirabilis bacteria used in this study were diluted in phosphate buffer solution, provided by the laboratory of analysis, treatment and valorization of environment pollutants and products of the Faculty of Pharmacia. The bacteria concentration stability over time was controlled with the optical density measurements. Potassium ferricyanide $\left(\mathrm{K}_{3}\left[\mathrm{Fe}(\mathrm{CN})_{6}\right]\right)$, potassium ferrocyanide $\left(\mathrm{K}_{4}\left[\mathrm{Fe}(\mathrm{CN})_{6}\right]\right)$, sodium chloride $(\mathrm{NaCl})$, potassium chloride $(\mathrm{KCl})$, sodium phosphate $\left(\mathrm{Na}_{2} \mathrm{HPO}_{4}\right)$, potassium phosphate $\left(\mathrm{KH}_{2} \mathrm{PO}_{4}\right)$, sulfuric acid $(98 \%)$, hydrogen peroxide (30\%), glutaraldehyde, PAH (poly (allylamine hydrochloride), PSS (poly (sodium 4-styrene sulfonate), bovine serum albumin (BSA), glycerol and glutaraldehyde were purchased from Sigma-Aldrich. The iron oxide carboxyl-modified magnetic nanoparticles (MNPs with a diameter of $200 \mathrm{~nm}$, density of carboxyl groups $>350 \mu \mathrm{mol} / \mathrm{g}$, stored in an aqueous suspension of $0.09 \% \mathrm{NaN}_{3}$ ) were obtained from Ademtech. Phosphate buffer saline (PBS) adjusted at pH 7.4 containing $137 \mathrm{mM} \mathrm{NaCl}, 2.7 \mathrm{mM} \mathrm{KCl}, 10 \mathrm{mM} \mathrm{Na}_{2} \mathrm{HPO}_{4}$ and $1.8 \mathrm{mM} \mathrm{KH}_{2} \mathrm{PO}_{4}$ was used. A $5 \mathrm{mM}$ of potassium ferricyanide/ ferrocyanide solution prepared in $\mathrm{PBS}$ was used in EIS and $\mathrm{CV}$ experiments.

*Corresponding author: Yosra Braham, Laboratory of Interfaces and Advanced Materials (LIMA), University of Monastir 5000, Tunisia, Tel: + (216) 78500278 , Fax: + (216) 78500 280; E-mail: braham.yosra@yahoo.fr

Received June 28, 2014; Accepted September 08, 2014; Published February 15,2015

Citation: Braham Y, Barhoumi H, Maaref A, Bakhrouf A, Heywang CG, et al (2015) Characterization of Urea Biosensor Based on the Immobilization of Bacteria Proteus Mirabilis in Interaction with Iron Oxide Nanoparticles on Gold Electrode. J Biosens Bioelectron 6: 160. doi: 10.4172/2155-6210.1000160

Copyright: ( $) 2015$ Braham Y, et al. This is an open-access article distributed under the terms of the Creative Commons Attribution License, which permits unrestricted use, distribution, and reproduction in any medium, provided the original author and source are credited. 
Citation: Braham Y, Barhoumi H, Maaref A, Bakhrouf A, Heywang CG, et al. (2015) Characterization of Urea Biosensor Based on the Immobilization of Bacteria Proteus Mirabilis in Interaction with Iron Oxide Nanoparticles on Gold Electrode. J Biosens Bioelectron 6: 160. doi: 10.4172/21556210.1000160

\section{Gold electrode cleaning}

Gold substrates were fabricated using standard silicon technologies. Silicon wafers were thermally oxidized to grow a $800 \mathrm{~nm}$-thick field oxide. Then, a $30 \mathrm{~nm}$ thick titanium layer and a $300 \mathrm{~nm}$ thick gold layer were deposited by evaporation. They were provided by the Laboratory of Analyze and Architecture of Systems (LAAS), CNRS Toulouse. Before the modification step, the plate gold electrodes $(1 \mathrm{~cm} \times 1 \mathrm{~cm})$ were cleaned in acetone solution for 20 min with ultrasonic bath. After that, they were dried under a nitrogen flow and then dipped for 1 min into a piranha solution of $\mathrm{H}_{2} \mathrm{SO}_{4} / \mathrm{H}_{2} \mathrm{O}_{2}(3: 1(\mathrm{v} / \mathrm{v}))$. Finally, the gold substrates were vigorously rinsed with ultrapure water and immediately immersed in an ethanol solution and finally dried under a nitrogen flow.

\section{Electrochemical and surface characterization methods}

Potentiometric measurements based on ion selective electrode (ISE): Potentiometric method based on ion-selective electrodes (ISEs) offers advantages such as simple procedure, relatively fast response time, non-destructive analysis, wide linear range with moderate selectivity $[9,10]$ and being extensively applied for the determination of many ions. In our work the potentiometric method was based on the measure of the potential or the ammonium ions concentration in the solution as function of the time when the Proteus mirabilis urease interacts with urea. The potentiometric measurements were carried out using ammonium selective electrode and $\mathrm{Ag} / \mathrm{AgCl}$ as reference electrode.

Electrochemical measurements: Electrochemical measurements were performed using a potentiostat-galvanostat (Voltalab-40) and the voltamaster 4 software with a conventional three-electrodes cell including a saturated calomel electrode (SCE) as the reference electrode, a platinum electrode $\left(0.45 \mathrm{~cm}^{2}\right)$ as the counter electrode and the modified gold electrode $\left(0.07 \mathrm{~cm}^{2}\right)$ as the working electrode. The impedance and cyclic voltammetry measurements were performed using the PBS as supporting electrolyte ( $\mathrm{pH}=7.4)$ containing $5 \mathrm{mM}$ of $\mathrm{Fe}(\mathrm{CN})_{6}^{3-/ 4-}$ as redox probe. The impedance spectra were recorded in a frequency range from $100 \mathrm{kHz}$ to $100 \mathrm{mHz}$ at the free potential of the used redox couple. The amplitude of the alternating voltage was $10 \mathrm{mV}$. All experiments were performed at $25^{\circ} \mathrm{C}$ in a Faraday cage.

Contact angle measurements: It is generally agreed that the physicochemical properties of bacterial cell and substratum surfaces are the main factors mediating bacterial adhesion [11-13]. It is assumed that bacterial cell and substratum hydrophobicity is the key parameter controlling the non-specific interactions of the adhesion process [14]. Contact angle measurements with three different liquids (Water, formamide and diiodomethane) were performed with contact angle instrument "Digidrop" model from the society GBX (Romans, France). Every reported contact angle measurements represent an average value of at least three separated drops on different areas of the given wafer. The size and volume of the drops were kept constant since then [15]. Furthermore, the surface energy components, the total energy $(\gamma \mathrm{s})$, the dispersive energy $\left(\gamma^{\mathrm{LW}}\right)$, the acid base energy $\left(\gamma^{A B}=2 \sqrt{\gamma^{+} \cdot \gamma^{-}}\right)$, the acid energy $(\gamma+)$ and the basic energy $\left(\gamma^{-}\right)$were determined from the wetting angle $(\theta)$ according to the Van Oss equation with polar and apolar liquids [16].

Atomic Force Microscopy (AFM): AFM experiments were performed on the NSI platform of LOMA (Bordeaux1), using the MultiMode NanoScope II apparatus (AFM imaging) and the Bioscope II, mounted on an Olympus inverted optical microscope and operating with the
NanosCope V controller (Veeco-Brucker, Santa Barbara, CA). This AFM is equipped with a piezo scanner (maximum XY scan range of $150 \mu \mathrm{m} \times 150 \mu \mathrm{m}$ with vertical range $\mathrm{Z}$ of $12 \mu \mathrm{m}$ ). For each experiment, three images are recorded at the same time: trace and retrace height images, trace deflection images (signal error) and phase images in tapping [17].

\section{Preparation of the Proteus mirabilis bacteria biosensors}

To ensure a high sensitivity and a good reproducibility of the biosensor, various working conditions were taken into account such as the presence of BSA and glycerol, the optimized nanoparticles concentration $(0.01 \mathrm{mg}$ of NPs in $500 \mu \mathrm{L}$ of PBS), the bacteria concentration $\left(10^{7} \mathrm{CFU} / \mathrm{mL}\right)$, the cross-linking time $(30 \mathrm{~min})$, the buffer solution concentration PBS $(10 \mathrm{mM})$ and the number of the polyelectrolyte layers $(n=3)$. In fact, the bacteria mixture was prepared by dissolving $5 \mathrm{mg}$ of BSA in $100 \mu \mathrm{L}$ of PBS bacteria solution, containing $10 \mu \mathrm{L}$ of glycerol at $\mathrm{pH} 7.4$.

The initial NPs suspension (1/500) was sonicated for $15 \mathrm{~min}$, then coated during $20 \mathrm{~min}$, with an initial "preconditioning" layer of PAH $(5 \mathrm{mg} / \mathrm{mL})$ which provides a positive charge, followed by a layer of PSS $(5 \mathrm{mg} / \mathrm{mL})$ of opposite charge to form the first polyelectrolyte (PE) bilayer $(n=1)$. The NPs were further coated sequentially with PEs, in the alternating order PAH/PSS until three bilayers, followed by a layer of PAH. We obtained (NPs-(PAH-PSS)n/PAH) with $n$ varies from 1 to 3 . The PE rich supernatant phase was then eliminated and the NPs were rinsed twice with ultrapure water. The modified electrode surface was covered with $10 \mu \mathrm{L}$ of nanoparticles coated with (PAH/PSS)3/ $\mathrm{PAH}$, then $10 \mu \mathrm{L}$ of the bacteria mixture. Finally, the NPs-(PAHPSS), ${ }_{3}$ PAH-Proteus mirabilis/Au modified electrode, (Figure 1) was kept in glutaraldehyde vapor for $30 \mathrm{~min}$ to allow the reticulation of the bacteria. After incubation, the electrode was rinsed with water to remove unbounded bacteria [18]. The modified electrode can then be used for electrochemical measurements and when not used it can be stored at $4^{\circ} \mathrm{C}$ (Figure 1). The biosensor treated by BSA, glutaraldehyde and glycerol allow a better adhesion, reticulation and a more regular distribution of bacteria without destroying the mechanical properties of the deposit membrane [19].

\section{Results and Discussion}

\section{The enzymatic kinetics of Proteus mirabilis-urease in solution}

The biochemical principle was based on the fact that urease from Proteus mirabilis catalyzes the hydrolysis of the transformation of urea into carbon dioxide and ammonium [20], according to the following reaction (1):

$$
\mathrm{CO}\left(\mathrm{NH}_{2}\right)_{2}+3 \mathrm{H}_{2} \mathrm{O} \stackrel{\text { Urease }}{\longrightarrow} \mathrm{CO}_{2}+2 \mathrm{NH}_{4}^{+}+2 \mathrm{OH}^{-}
$$

Figure 2 shows an increase of ammonium ion concentration when the injected urea concentration increases. This catalytic phenomenon can be illustrated by the kinetic behavior of the enzymatic reaction according to the concentration of the urea in solution. Furthermore, urea penetrates in bacterial cells via transport system and complex with urease in the cytoplasmic membrane. This attests the permeability of Proteus mirabilis membrane to urea. According to Figure 2, the curve corresponding to urea concentration $1.14 \mathrm{mM}$ enables us to determine the activity of urease from Proteus mirabilis. This kinetic obeys to the Michaelis low and shows that the response increases with time, until reaching a plateau for ammonium ion concentrations higher or equal to $18 \mathrm{mM}$, corresponding to the saturation of urease active sites by urea molecules. We can conclude that the enzymatic activity of urease in 


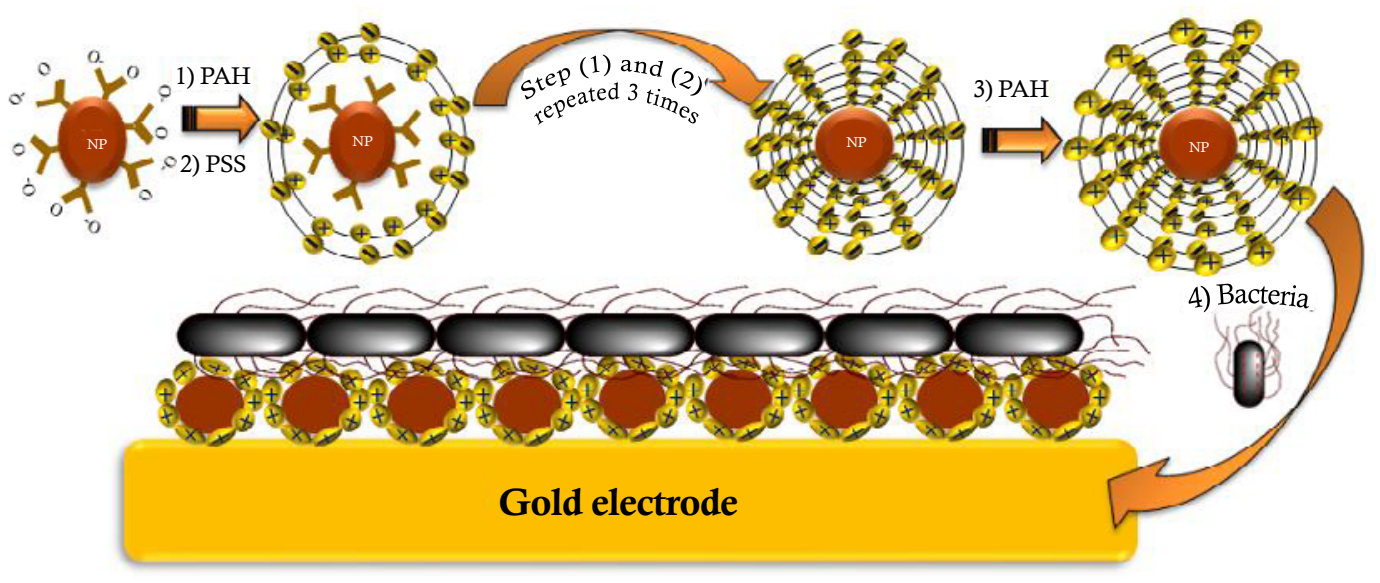

Figure 1: Schematic of the biosensor elaboration using $\mathrm{Fe}_{3} \mathrm{O}_{4}$ nanoparticles.

solution is equal to $20 \mu \mathrm{mol}$. $\mathrm{min}^{-1}$.

\section{AFM characterization of the modified gold electrode surface}

The atomic force microscopy (AFM) has enabled us to deepen our study of film formation and optimize some parameters of deposit protocols. In particular, the effect of nanoparticles, the influence of the rinsing between steps, and cleaning protocol of the electrodes, which allowed us to ensure uniformity and cleanliness of the surface, the adsorption film, the deposition efficiency, and the immobilization of bacteria. This method also gave us the opportunity to determine the size of used nanoparticles and bacteria. Figure 3, shows the height AFM image of the gold electrode treated for different scales 5 and $1 \mu \mathrm{m}$. This image shows the effectiveness of cleaning protocol with the piranha solution. Figure 4 presents the aggregated nanoparticles, but our aim is to have isolated nanoparticles and to avoid the formation of aggregates. To optimize the concentration of nanoparticles a dilution step was adopted. In fact, different solutions of nanoparticles were tested and the corresponding solution was deposited on the bare electrode with stirring under ultrasound during each deposition step. Figure 5, shows a good dispersion of nanoparticles on the surface of electrode by the mixing of the nanoparticles initial solution $1 \mu \mathrm{L}$ with $500 \mu \mathrm{L}$ of ultrapure water $(0.01 \mathrm{mg} / \mathrm{mL})$ at $\mathrm{pH}=7$ and by applying ultrasonic dispersion for 15 minutes. Indeed it has been determined by AFM the nanoparticles size, it is approximately $290 \mathrm{~nm}$ in length, $270 \mathrm{~nm}$ width and $177 \mathrm{~nm}$ in height. From Figure 6 we can observe that the analysis of a deposit comprising nanoparticles coated with 3 and half bilayers of poly-electrolytes, shows a completely covered surface, with visible homogeneity at large scale of $\left(10^{\star} 10 \mu \mathrm{m}^{2}\right)$.

The biofilm of bacteria was formed on bare gold electrode surface and by immobilization through the coated nanoparticles with polyelectrolytes process. The first method is limited, since the surface density of immobilized bacteria is weak and a lot of them are removed during the rinsing phase leading to poorly reproducible biosensor. Figure 7 shows a carpet of rod bacillus bacterium adhered on the surface of the electrode in the presence of magnetic nanoparticles. We can clearly see the flagella of these bacteria that can ensure their mobility. From the Figure 8 it is noted that the conformation of the bacteria is unchanged in the presence of magnetic iron nano-particles that shows a non-inhibitory effect of the latter. Previous work has shown that iron nanoparticles exhibit an inhibitory effect on the enzymes such as urease [7]. In our case the urease is in a favorable environment and protected by the membrane of the bacterium. This organism has a good resistance

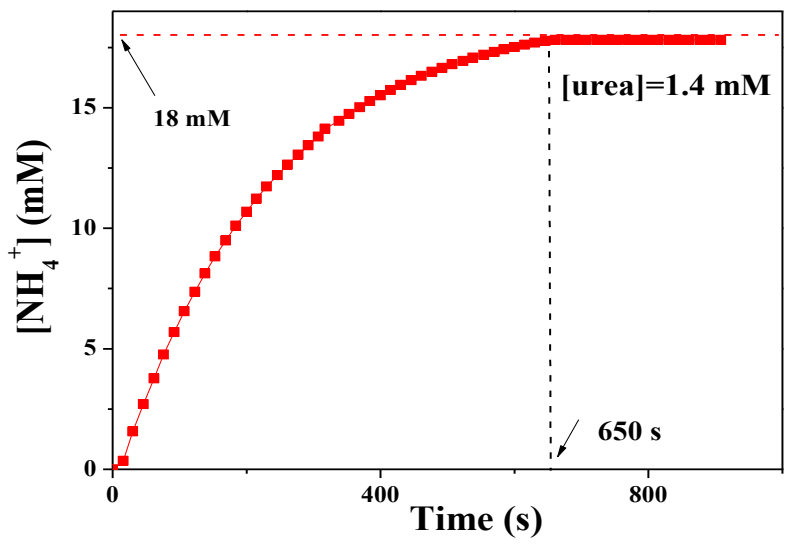

Figure 2: Kinetic behavior of the enzymatic reaction according to the urea concentration in solution.

against certain inhibitors such as nanoparticles [21].

After the step of functionalization of gold electrodes with nanoparticles and polyelectrolytes, we deposited bacteria. The topographic results in tapping mode are shown in Figure 9. These observations confirm the adhesion of bacteria on coated nanoparticles. AFM allows us to determine the size of the Proteus mirabilis bacteria which it is approximately $1.8 \mu \mathrm{m}$ in length, $0.9 \mu \mathrm{m}$ in width and 0.2 $\mu \mathrm{m}$ in height Figure 10. These values are in good agreement with the bacteria size given by the literature [22].

\section{Contact angle measurements and adhesion tests}

Contact angle can be used as powerful technique to check the effectiveness of the functionalization process. In our work we have used three liquids with different polarities (water, formamide and diiodomethane) for hydrophilic/hydrophobic character and surface energy determination (Figure 11). In fact, the contact angle measurements obtained with different test liquids, were done on the bare and the modified gold electrode. The wetting properties have been compared before and after the functionalization process. The values of the contact angles with the different probe liquids and surface energy components for the substrate surfaces and the deposit membranes are summarized in Table 1. 
Citation: Braham Y, Barhoumi H, Maaref A, Bakhrouf A, Heywang CG, et al. (2015) Characterization of Urea Biosensor Based on the Immobilization of Bacteria Proteus Mirabilis in Interaction with Iron Oxide Nanoparticles on Gold Electrode. J Biosens Bioelectron 6: 160. doi: 10.4172/21556210.1000160
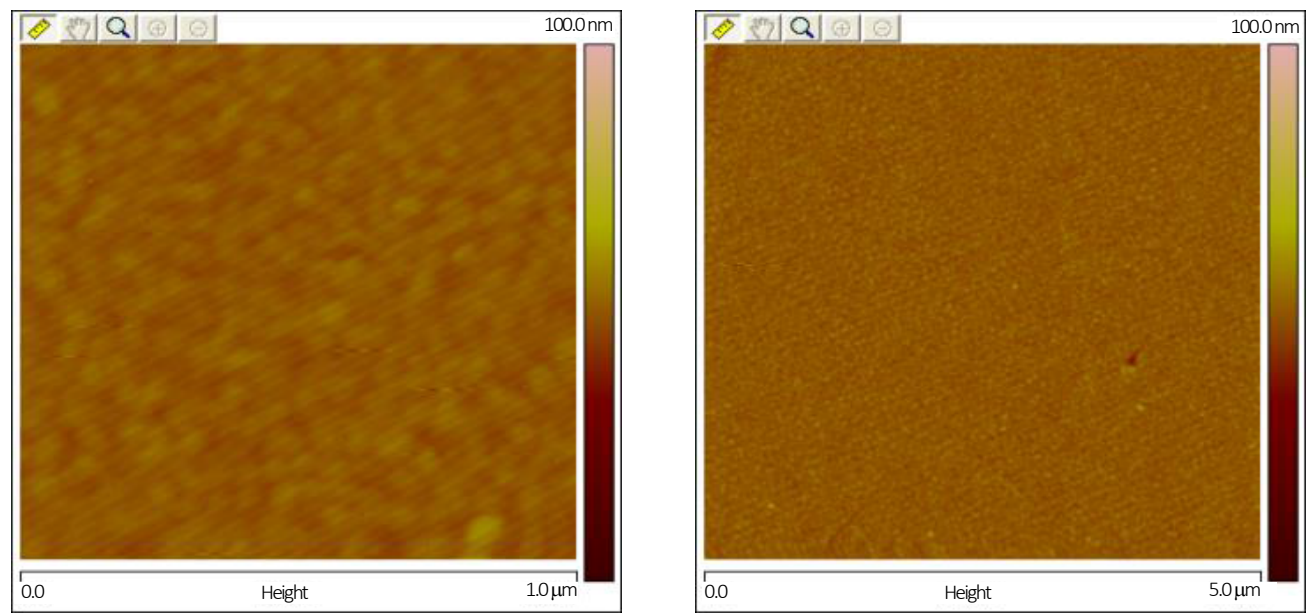

Figure 3: Height image $\left(1 \mu \mathrm{m}^{*} 1 \mu \mathrm{m}\right.$ and $\left.5 \mu \mathrm{m}^{\star} 5 \mu \mathrm{m}\right)$ obtained in AFM with the tapping mode on bare electrode.

\section{Height image}

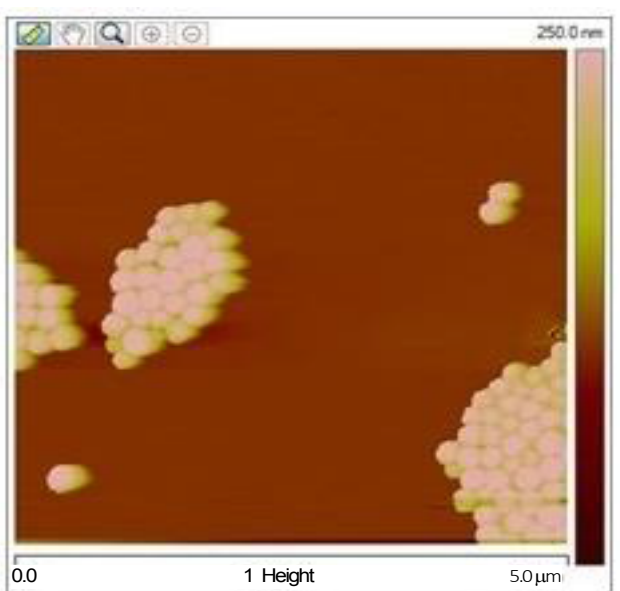

Amplitude image

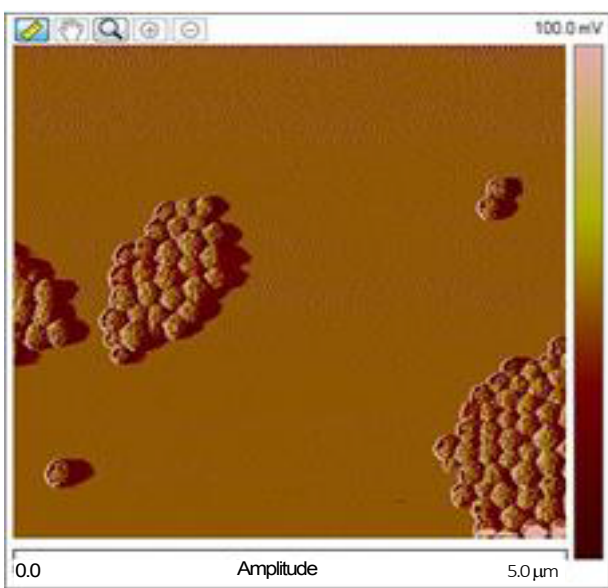

Figure 4: Height and amplitude images $\left(5 \mu \mathrm{m}^{\star} 5 \mu \mathrm{m}\right)$ of aggregated nanoparticles obtained in AFM with the tapping mode on bare electrode.
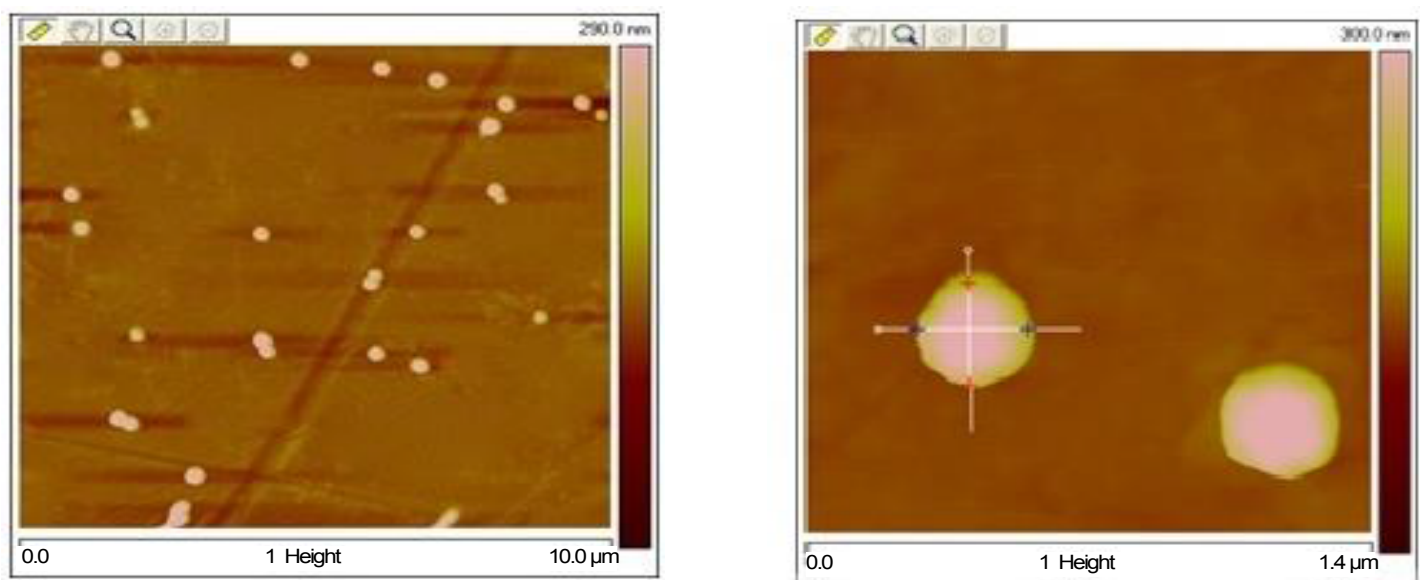

Figure 5: Height images $\left(10 \mu \mathrm{m}^{*} 10 \mu \mathrm{m}\right.$; and $\left.1.4 \mu \mathrm{m}^{*} 1.4 \mu \mathrm{m}\right)$ of dispersed nanoparticles obtained in AFM with the tapping mode on bare electrode. 
Citation: Braham Y, Barhoumi H, Maaref A, Bakhrouf A, Heywang CG, et al. (2015) Characterization of Urea Biosensor Based on the Immobilization of Bacteria Proteus Mirabilis in Interaction with Iron Oxide Nanoparticles on Gold Electrode. J Biosens Bioelectron 6: 160. doi: 10.4172/21556210.1000160

\section{Height image}

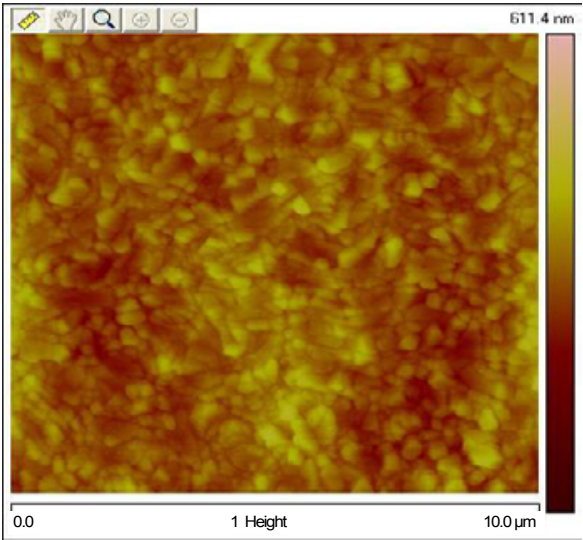

Amplitude image

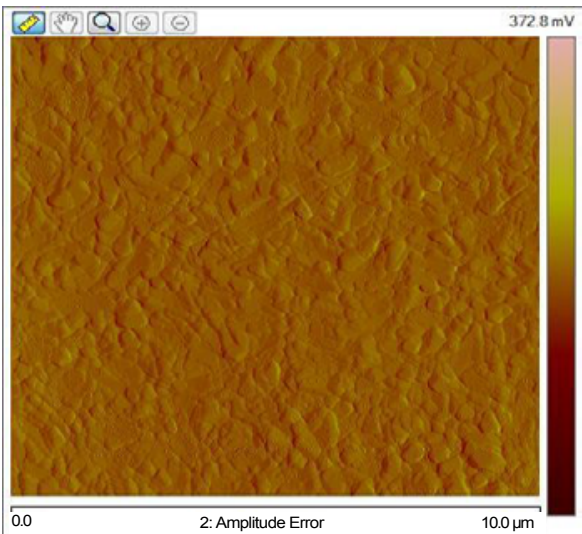

Figure 6: Height and amplitude images $\left(10 \mu \mathrm{m}^{*} 10 \mu \mathrm{m}\right)$ obtained in AFM with the tapping mode for surfaces functionalized with a mixture of NPs $+(\mathrm{PAH}-\mathrm{PSS})_{3}-\mathrm{PAH}$.

Height image

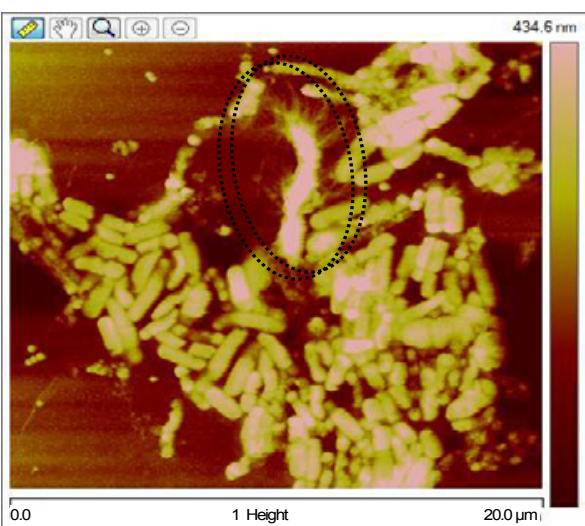

Amplitude image

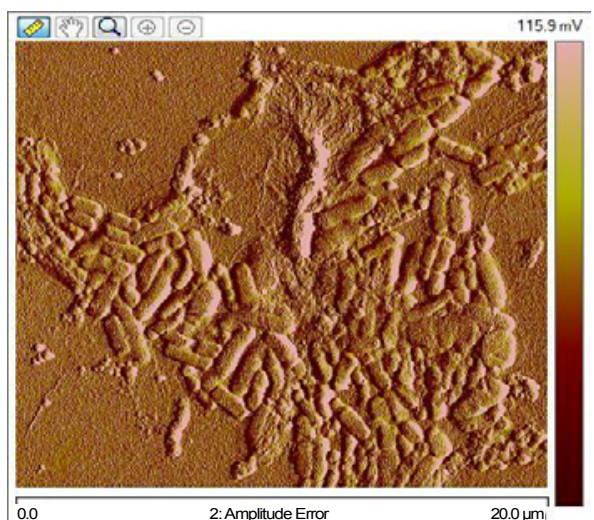

$20.0 \mu \mathrm{m}$

Figure 7: Height and amplitude images $\left(20 \mu \mathrm{m}^{\star} 20 \mu \mathrm{m}\right)$ obtained in AFM with the tapping mode for surfaces modified with a mixture of NPs and bacteria.
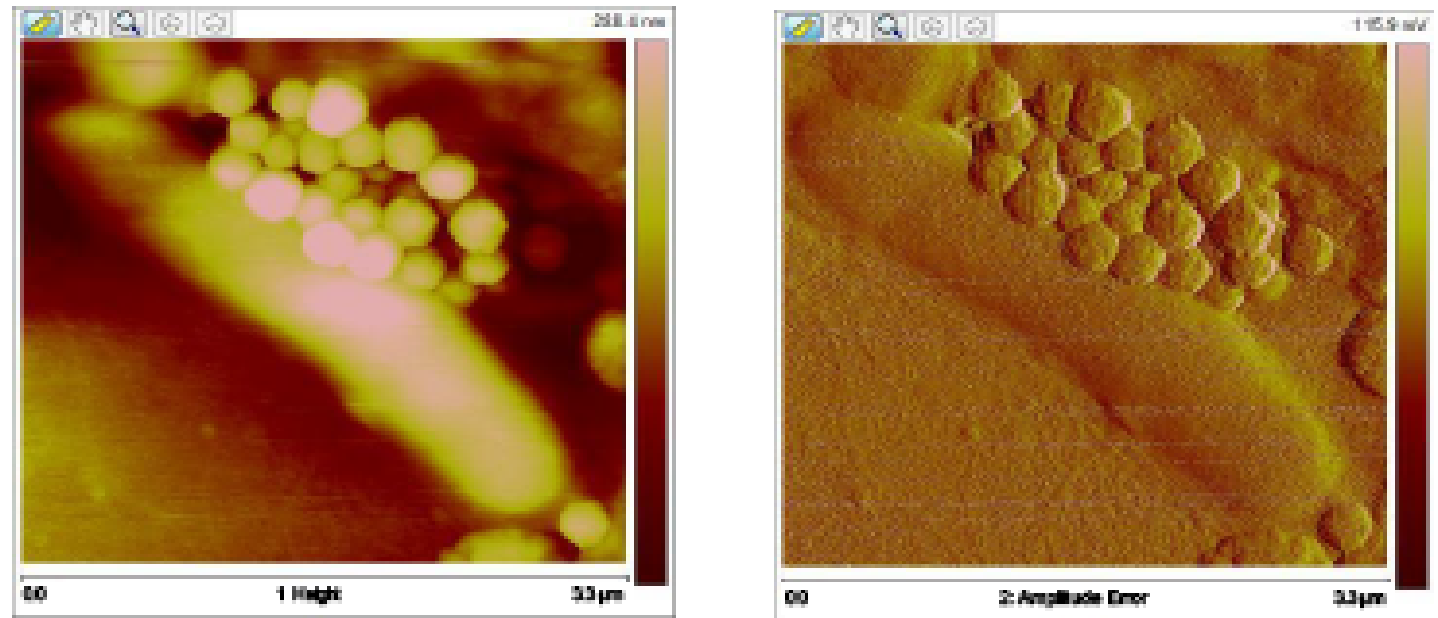

Figure 8: Height and amplitude images $\left(3,3 \mu \mathrm{m}^{\star} 3,3 \mu \mathrm{m}\right)$ obtained in AFM with the tapping mode of bacteria interacting with nanoparticles. 
Citation: Braham Y, Barhoumi H, Maaref A, Bakhrouf A, Heywang CG, et al. (2015) Characterization of Urea Biosensor Based on the Immobilization of Bacteria Proteus Mirabilis in Interaction with Iron Oxide Nanoparticles on Gold Electrode. J Biosens Bioelectron 6: 160. doi: 10.4172/21556210.1000160

\section{Height image}

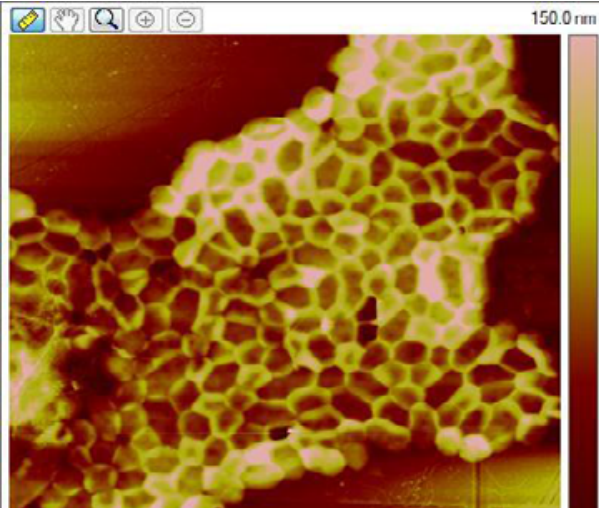

Amplitude image

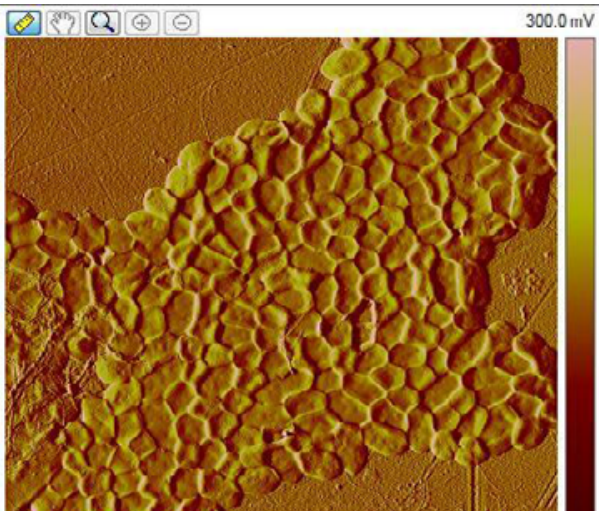

Figure 9: Height and amplitude images $\left(20 \mu \mathrm{m}^{\star} 20 \mu \mathrm{m}\right)$ obtained in AFM with the tapping mode for Proteus mirabilis biosensor.

\section{Height image}

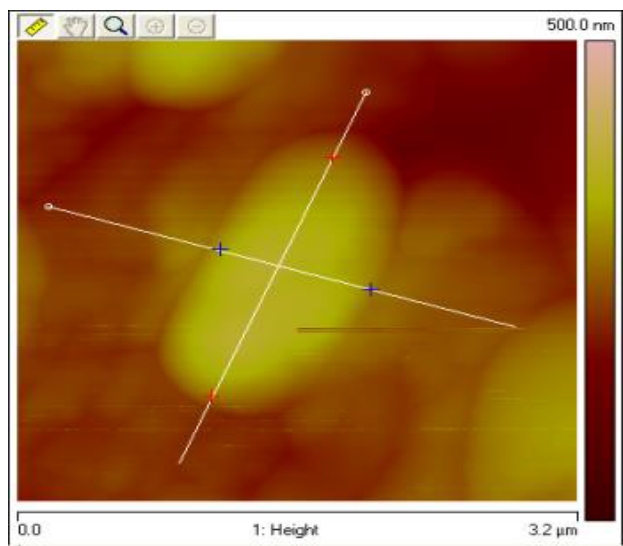

Amplitude image

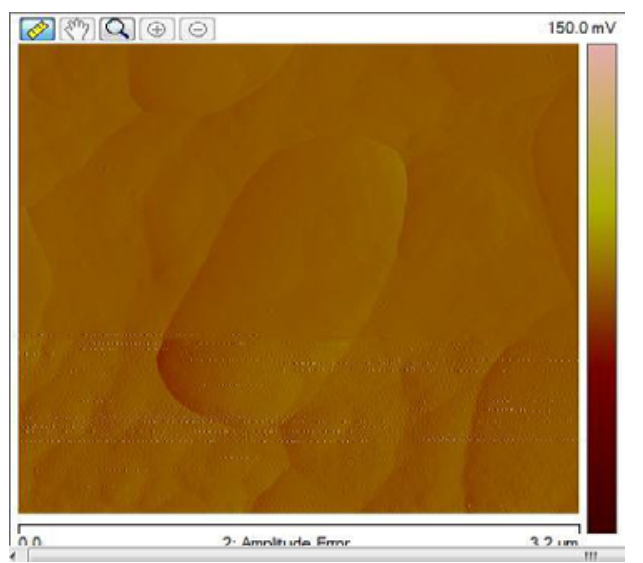

Figure 10: Height and amplitude images $\left(3.2 \mu \mathrm{m}^{\star} 3.2 \mu \mathrm{m}\right)$ obtained in AFM with the tapping mode for Proteus mirabilis bacteria

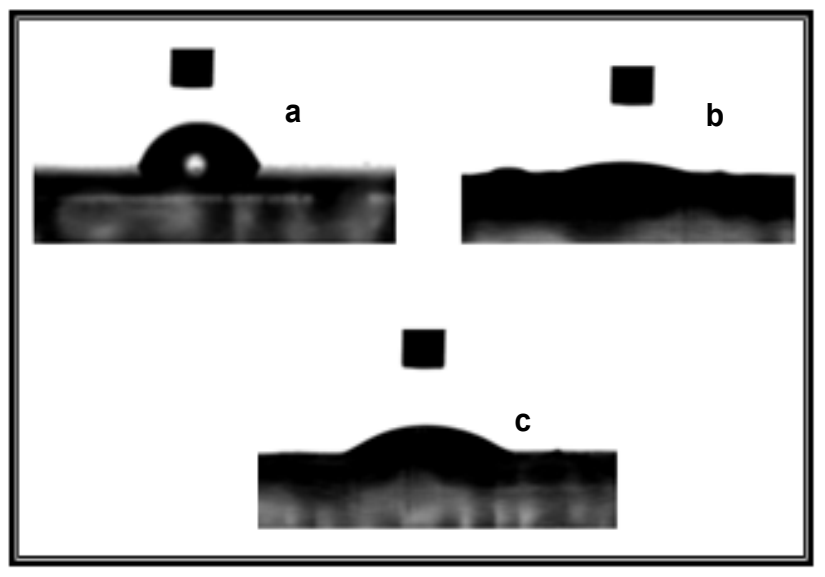

Figure 11: Schematic representation of contact angles with water for bare gold $\theta=71.7^{\circ}(\mathrm{a})$; Proteus mirabilis $\theta=18.1^{\circ}(\mathrm{b}) ; \mathrm{Au} / \mathrm{NPs}-(\mathrm{PAH} / \mathrm{PSS})_{3} / \mathrm{PAH} /$ Proteus mirabilis $\theta=39.1^{\circ}$ (c)
In addition, repetitive contact angle measurements were carried out for the same modified surface and the deviation is about $\pm 3^{\circ}$.

The contact angle measurements show that the hydrophobic Au surface acquires a hydrophilic character when it is functionalized with the Proteus mirabilis bacteria. As a result, an increase in the basic energy $\left(\gamma^{-}\right)$of the modified surface was observed due to the hydroxide $(\mathrm{OH})$ and the carboxyl $(\mathrm{COOH})$ groups localized in Proteus mirabilis bacteria and nanoparticles [23]. Table 2, presents the contact angles obtained using different probe liquids for Proteus mirabilis suspended in PBS and deposited on cellulose acetate membrane filters. With a contact angle of $18^{\circ}$ we conclude that the bacterial cell presents a hydrophilic character. In adhesion phenomenon the contribution of the electrostatic forces is important, since bacteria adsorbed layer on $\mathrm{Au}$ electrode have generally negative surface potentials, giving rise to repulsive electrostatic interactions. Although, additional polyelectrolyte $\mathrm{PAH}$ layer reduces the repulsion effect and enhances the adhesion according to the positive charge generated by the $-\mathrm{NH}_{3}^{+}$ cationic groups.

Using the thermodynamic approach of the Lifshitz van der Waals $(\mathrm{LW})$ and the acid/base $(\mathrm{AB})$ interactions, the total adhesion energy 
Citation: Braham Y, Barhoumi H, Maaref A, Bakhrouf A, Heywang CG, et al. (2015) Characterization of Urea Biosensor Based on the Immobilization of Bacteria Proteus Mirabilis in Interaction with Iron Oxide Nanoparticles on Gold Electrode. J Biosens Bioelectron 6: 160. doi: 10.4172/21556210.1000160

Page 7 of 9

$\Delta \mathrm{G}_{\text {adh }}$ Total of a bacterium to a substratum surface in a suspending liquid can be calculated as the sum of the $\mathrm{LW}$ component $\Delta \mathrm{G}_{\text {adh }}{ }^{\mathrm{LW}}$ and the $\mathrm{AB}$ component $\Delta \mathrm{G}_{\mathrm{adh}}^{\mathrm{AB}}[24-26]$.

$$
\begin{gathered}
\Delta G_{a d h}^{T o t a l}=\Delta G_{a d h}^{L W}+\Delta G_{a d h}^{A B} \\
\Delta G_{a d h}^{L W}=\left(\sqrt{\gamma_{B}^{L W}}-\sqrt{\gamma_{S}^{L W}}\right)^{2}-\left(\sqrt{\gamma_{B}^{L W}}-\sqrt{\gamma_{L}^{L W}}\right)^{2}-\left(\sqrt{\gamma_{S}^{L W}}-\sqrt{\gamma_{L}^{L W}}\right)^{2} \\
\Delta G_{a d h}^{A B}=2\left[\sqrt{\gamma_{L}^{+}}\left(\sqrt{\gamma_{B}^{-}}+\sqrt{\gamma_{S}^{-}}-\sqrt{\gamma_{L}^{-}}\right)+\sqrt{\gamma_{L}^{-}}\left(\sqrt{\gamma_{B}^{+}}+\sqrt{\gamma_{S}^{+}}-\sqrt{\gamma_{L}^{+}}\right)-\sqrt{\gamma_{B}^{-} \gamma_{S}^{+}}-\sqrt{\gamma_{B}^{+} \gamma_{S}^{-}}\right]
\end{gathered}
$$

The prediction of the thermodynamic approach states that adhesion may occur if $\Delta \mathrm{G}_{\text {adh }}$ Total is negative and it is energetically unfavorable if $\Delta \mathrm{G}_{\text {adh }}$ Total is positive. Using Equations (2), (3) and (4), the values of the interfacial free energy of adhesion of Proteus mirabilis to the gold electrodes and its components (LW and $\mathrm{AB})$ are calculated and presented in Table 3.

According to the thermodynamic approach, the negative value of the estimated energy demonstrates that the adhesion is favorable (Table 3). In fact, the adhesion process is governed by the electrostatic interactions. As a result, the negative value of the LW adhesion energy component indicates that the adhesion was favorable onto the NPs(PAH-PSS) $/ 3$ PAH modified Au surfaces with estimated total adhesion energy values of $-11.2 \mathrm{~mJ} / \mathrm{m}^{2}$. This high adhesion energy indicates that Proteus mirabilis bacteria adhere strongly to the hydrophobic $\mathrm{Au}$ surface.

\section{Electrochemical characterizations of the Proteus mirabilis biosensor}

The cyclic voltammogram of soluble electro active species provides a convenient tool to monitor the various stages of the biosensor buildup on Au electrode. The Figure 12A shows the cyclic voltammograms of $5 \mathrm{mM}\left[\mathrm{Fe}(\mathrm{CN})_{6}\right]^{4-3-}$ probe for the bare and the modified Au electrodes in PBS, $\mathrm{pH} 7.4$, at scan rate of $100 \mathrm{mVs}^{-1}$. The Au surface was modified with nanoparticles, NPs-(PAH-PSS) ${ }_{3} / \mathrm{PAH}-$ Proteus mirabilis. It can be seen that for a bare Au electrode, a characteristic quasi-reversible redox cycle with anodic and cathodic peak currents were obtained. When the $\mathrm{Au}$ surface was functionalized with nanoparticles and bacteria, the electron transfer between the redox probe and the modified surface was changed. As a result, an obvious decrease of the anodic and the cathodic peaks was observed leading to a high $\Delta \mathrm{Ep}$ value $(295 \mathrm{mV})$ indicating the formation of the bioactive layer.

Electrochemical impedance spectroscopy can also give detailed information on the dielectric constant and the barrier properties of the deposit layer changes. Figure 12B shows the impedance spectra of the bare and the modified gold electrode. The bare Au electrode reveals a very small semicircle, implying a very low electron-transfer resistance $\left(\mathrm{R}_{\mathrm{et}}\right)$ of the redox probe. When the electrode is modified with NPs-(PAH-PSS) ${ }_{3} / \mathrm{PAH}-$ Proteus mirabilis film, the Ret increases significantly. The deposit film was defined with negatively charged ( $\left.\mathrm{COO}^{-}\right)$of bacteria which acts as an electrostatic barrier that resists to the $\left[\mathrm{Fe}(\mathrm{CN})_{6}\right]^{4-13-}$ redox probe and hinders its ability to diffuse into the layer. As a result, this phenomenon retards the electron transfer kinetics between the redox probe and the surface of the modified electrode. We note that the electrochemistry of the NPs-(PAH-PSS) ${ }_{3} / \mathrm{PAH}-$ Proteus mirabilis/Au modified electrode surface is still observable, indicating that the polyelectrolyte layers does not provide a very effective barrier between the electrolyte and the gold surface. The change in the charge transfer resistance is related to the electrode coverage $\tau$ and is given by the relation as shown in the following relation (2):

$$
\tau(\%)=\frac{R_{e}-R_{t}{ }^{0}}{R_{e}} \times 100
$$

Where $\tau$ is the apparent electrode coverage, $\mathrm{R}_{\mathrm{et}}{ }^{\circ}$ and $\mathrm{R}_{\mathrm{et}}$ are the electron transfer resistance measured at the bare and the modified $\mathrm{Au}$ electrode, respectively. The coverage rates $(\tau)$ of the modified electrode were reported in Table 4 . As a result, a higher coverage rate was observed for NPs-(PAH-PSS) 3 /PAH-Proteus mirabilis/Au electrode.

The impedance data were fitted to a simple Randles equivalent circuit presented in the Figure 13 which was made up of a parallel combination of the solution resistance $\left(\mathrm{R}_{\mathrm{s}}\right)$, the electron transfer resistance $\left(R_{e t}\right)$, the constant phase element $\left(C_{d d}\right)$ and the Warburg impedance element $(W)$. Thus, $R_{e t}$ was a suitable signal for sensing the interfacial properties of the prepared biosensor during the assembly procedure. Table 4 presents the equivalent circuit parameters of the numeric simulation curves as characteristic of the various steps of the biosensor elaboration.

\section{Study of the urea concentration effect}

The impedance sensor responses to various urea concentrations were made with NPs-(PAH-PSS)/PAH-Proteus mirabilis in PBS solution ( $\mathrm{pH}$ 7.4). Electrochemical measurements have been achieved under a free potential and varying frequency from $100 \mathrm{kHz}$ to 100 $\mathrm{mHz}$. Figure 14A shows the impedance spectra of the modified gold electrode for different urea concentrations. The obtained curve has a semi-circle geometrical form. As can be seen, the diameter of the semicircle decreases when the urea concentration increases. The detection mechanism can be explained by the interaction between urea and urease biomolecule inside the Proteus mirabilis bacteria. Indeed, as

\begin{tabular}{|c|c|c|c|c|c|c|c|c|}
\hline \multicolumn{4}{|c|}{ Contact angle $\left({ }^{\circ}\right)$} & \multicolumn{5}{|c|}{ Surface energy components $\left(\mathrm{mJ} / \mathrm{m}^{2}\right)$} \\
\hline Surface & Water & Formamide & Diiodo-methane & $Y^{t W}$ & $\mathrm{~V}^{\mathrm{AB}}$ & $\mathrm{Y}^{+}$ & $\mathbf{Y}$ & $\mathrm{Y}^{\text {Totat }}$ \\
\hline Bare Au & 71.7 & 31.4 & 31 & 43.8 & 5.6 & 2.4 & 3.3 & 49.4 \\
\hline $\mathrm{Au} / \mathrm{NPs}-(\mathrm{PAH}-\mathrm{PSS})_{3} / \mathrm{PAH}$ & 93.0 & 43.3 & 43.1 & 40.1 & 9.0 & 8.6 & 3.2 & 41.2 \\
\hline $\mathrm{Au} / \mathrm{NPs}-(\mathrm{PAH}-\mathrm{PSS})_{3} / \mathrm{PAH}-$ Proteus mirabilis & 39.1 & 43.0 & 37.5 & 40.8 & 0.3 & 0 & 47.9 & 41.2 \\
\hline
\end{tabular}
the products of the urea hydrolysis are alkaline, an increase of urea concentration in the analyzed solution causes an increase of $\mathrm{pH}$ near

\begin{tabular}{|c|c|c|c|c|c|c|c|c|}
\hline & \multirow[b]{2}{*}{ Water } & \multicolumn{2}{|c|}{ Contact angle $\left({ }^{\circ}\right)$} & \multicolumn{5}{|c|}{ Surface energy components $\left(\mathrm{mJ} / \mathrm{m}^{2}\right)$} \\
\hline & & Formamide & Diiodomethane & 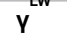 & V & $y^{+}$ & Y & $y$ \\
\hline Proteus mirabilis & 18.1 & 20.2 & 41.8 & 37.6 & 15.8 & 1.3 & 55.6 & 53.5 \\
\hline PBS $^{b}$ & - & - & - & 22.0 & 35.2 & 17.6 & 17.6 & 57.2 \\
\hline
\end{tabular}
the modified surface of the biosensor. Then this variation of $\mathrm{pH}$ causes

Table 1: Contact angles and surface energy components of the bare and the modified Au electrode.

${ }^{\mathrm{D}}$ The values of $\mathrm{Y}^{\mathrm{LW}}$ and $\mathrm{Y}^{\mathrm{AB}}$ are taken from published data [22].

${ }^{\mathrm{b}}$ The values of $\mathrm{Y}^{\mathrm{LW}}$ and $\mathrm{Y}^{\mathrm{AB}}$ are taken from published data [22]

Table 2: Contact angles measurements of Proteus mirabilis suspended in PBS. 
Citation: Braham Y, Barhoumi H, Maaref A, Bakhrouf A, Heywang CG, et al. (2015) Characterization of Urea Biosensor Based on the Immobilization of Bacteria Proteus Mirabilis in Interaction with Iron Oxide Nanoparticles on Gold Electrode. J Biosens Bioelectron 6: 160. doi: 10.4172/21556210.1000160

Page 8 of 9

\begin{tabular}{|l|c|c|c|}
\hline Materials & $\boldsymbol{\Delta} \mathbf{G}_{\text {adh }}{ }^{\mathrm{LW}}\left(\mathbf{m} \mathbf{J} / \mathbf{m}^{2}\right)$ & $\boldsymbol{\Delta} \mathbf{G}_{\text {adh }}{ }^{\mathrm{AB}}\left(\mathbf{m} \mathbf{J} / \mathbf{m}^{2}\right)$ & $\Delta \mathbf{G}_{\text {adh }}{ }^{\text {totale }}\left(\mathbf{m J} / \mathbf{m}^{2}\right)$ \\
\hline $\mathbf{A u}$ & -5.5 & 2.7 & -2.8 \\
\hline Au/NPs-(PAH-PSS) ${ }_{3}$ PAH & -4.7 & -6.4 & -11.2 \\
\hline
\end{tabular}

Table 3: Lifshitz van der Waals $\left(\Delta \mathrm{G}_{\text {adh }}{ }^{\mathrm{LW}}\right)$, acid/base $\left(\Delta \mathrm{G}_{\text {adh }}{ }^{\mathrm{AB}}\right)$ and total $\left(\Delta \mathrm{G}_{\text {adh }}{ }^{\text {Total }}\right)$ interfacial free energy of adhesion of Proteus mirabilis on Au surfaces (in millijoules per square meter)

\begin{tabular}{|l|c|c|c|c|c|c|}
\hline & $\mathbf{\Delta E p}(\mathbf{m V})$ & $\mathbf{R s}(\mathbf{\Omega})$ & $\mathbf{C}_{\mathrm{dl}}(\boldsymbol{\mu F})$ & $\mathbf{R}_{\mathrm{et}}(\mathbf{\Omega})$ & $\mathbf{X}^{\mathbf{2}}\left(\mathbf{1 0}^{-\mathbf{3}}\right)$ & $\mathbf{T} \mathbf{( \% )}$ \\
\hline $\mathbf{A u}$ & 103 & 210 & 7.2 & 760 & 1.4 & 0 \\
\hline $\begin{array}{l}\text { Au/NPs-(PAH-PSS) } \\
\text { PAH- Proteus mirabilis }\end{array}$ & 295 & 225 & 6.7 & 5350 & 3.2 & 85 \\
\hline
\end{tabular}

Table 4: Impedance parameters of the deposited layers on gold electrode obtained by experimental fitting data to the equivalent circuit model.
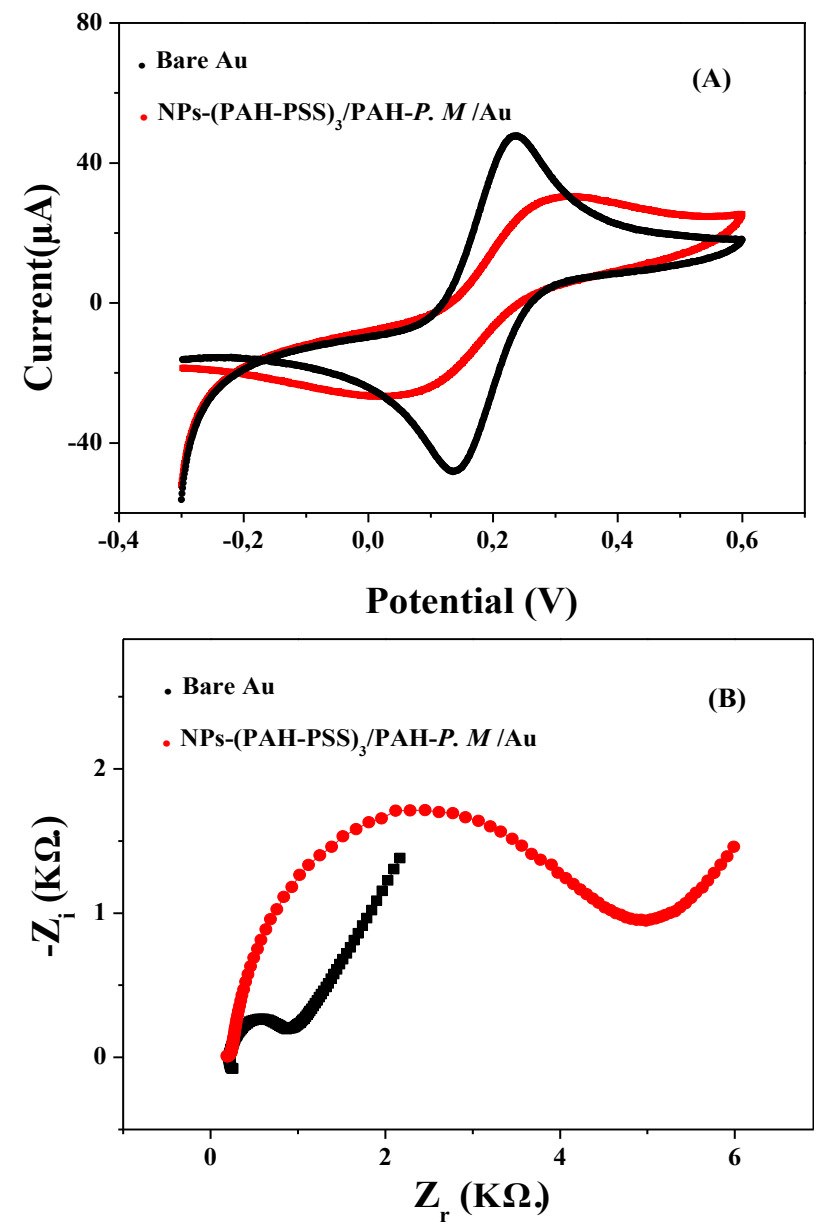

Figure 12: Cyclic voltammograms, at scan rate of $100 \mathrm{mVs}^{-1}(\mathrm{~A})$ and $(B)$ the Nyquist plots using a frequency range of $100 \mathrm{kHz}$ to $100 \mathrm{mHz}$ for the bare Au electrode and NPs-(PAH-PSS) 3 /PAH-Proteus mirabilis/Au modified electrode.

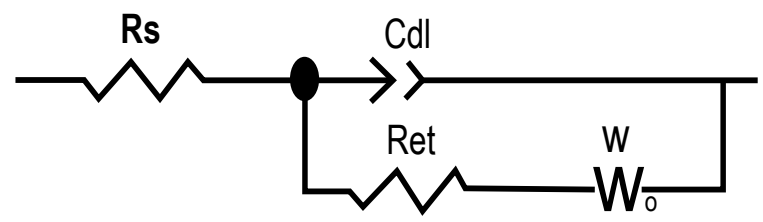

Figure 13: The equivalent circuit model applied to simulate the impedance spectroscopy data. a variation of the electrode impedance which can be detected. In the Figure $14 \mathrm{~B}$ the calibration curve shows the variation of the transfer resistance versus the urea concentration. As a result, we observe that the impedance biosensor demonstrates a good response to urea addition with high electrochemical performances. A linear relationship between the electron transfer resistance and the p[urea] was obtained with a good correlation coefficient $\left(\mathrm{R}^{2}=0.997\right)$. Therefore, a sensitivity of $327.7 \Omega / \mathrm{p}$ [Urea], a detection limit of $10^{-4.92} \mathrm{M}$ and a dynamic range from $10^{-2} \mathrm{M}$ to $10^{-5} \mathrm{M}$ were obtained. The obtained result using bacteria was improved in comparison with other results reported in previous works based on urea biosensors fabricated using urease as active biomolecule $[27,28]$.

\section{Conclusion}

In this work, we developed a sensitive biosensor for urea detection. At first, magnetic nanoparticles were deposited on the bare gold electrode. Then bacteria were immobilized on the magnetic nanoparticles by physical adsorption using polyelectrolytes PAH and PSS. During the development of multilayer, the deposition steps have been evaluated and characterized by electrochemical method, contact angle measurements and AFM topographic technical. The biosensor
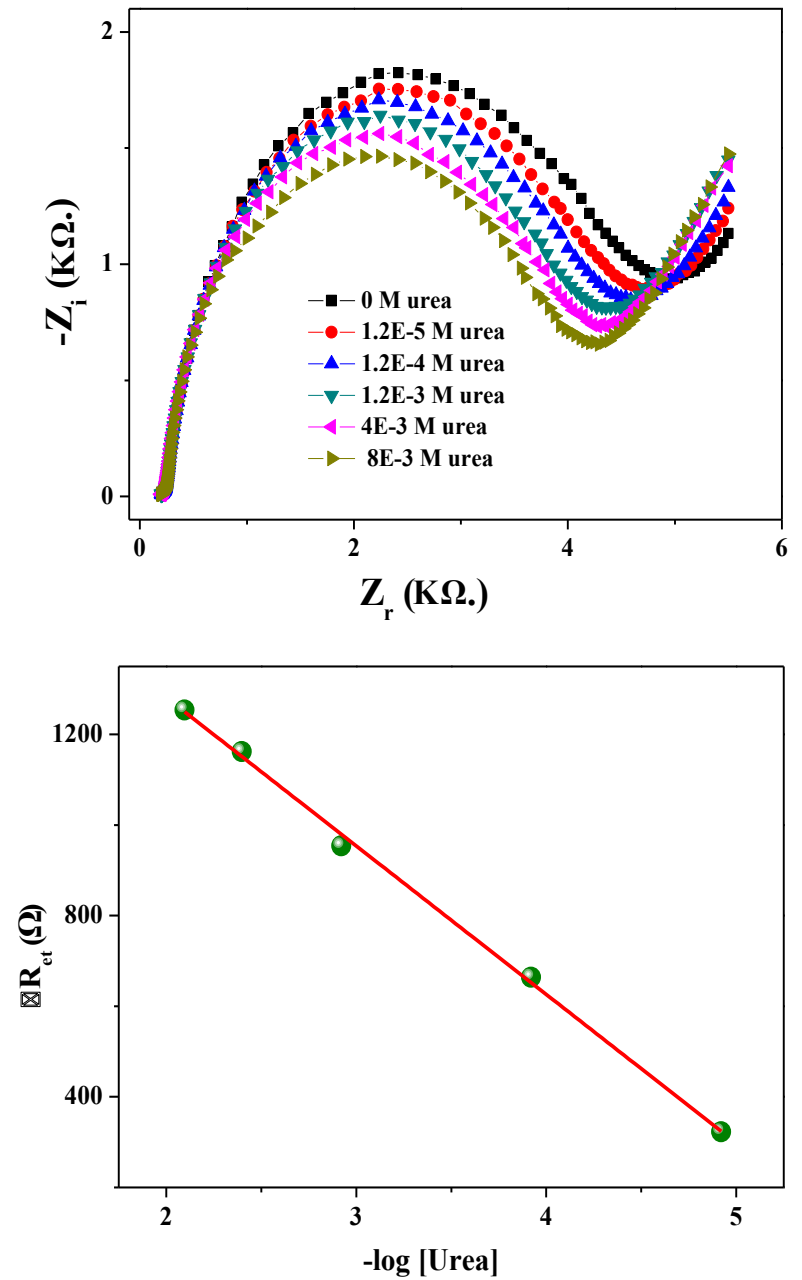

Figure 14: Nyquist plot of each individual urea concentration in PBS solution $(\mathrm{pH} 7.4)(\mathrm{A})$ and $(\mathrm{B})$ the calibration curve of the impedimetric urea biosensor. 
Citation: Braham Y, Barhoumi H, Maaref A, Bakhrouf A, Heywang CG, et al. (2015) Characterization of Urea Biosensor Based on the Immobilization of Bacteria Proteus Mirabilis in Interaction with Iron Oxide Nanoparticles on Gold Electrode. J Biosens Bioelectron 6: 160. doi: 10.4172/21556210.1000160

Page 9 of 9

developed was applied to the determination of urea. Thanks to the presence of bacteria as optimized environment for urease the biosensor can be used as indicator of urea for medical analysis.

\section{References}

1. Gupta G, Rajendran V, Atanassov (2003) Laccase Biosensor on MonolayerModified Gold Electrode, Electroanalysis 15: 1577-1583.

2. Yang Z, Zhang C, Zhang J, Bai W (2014) Potentiometric glucose biosensor based on core-shell Fe3O4-enzyme-polypyrrole nanoparticles. Biosensors and Bioelectronics 51: 268-273.

3. Baghayeri M, Zare EN, Lakouraj MM (2014) A simple hydrogen peroxide biosensor based on a novel electro-magnetic poly(p-phenylenediamine)@ Fe3O4 nanocomposite. Biosensors and Bioelectronics. 55: 259-265.

4. Ghaedi M, Nejati Biyareh M, Nasiri Kokhdan S, Shamsaldini S, Sahraei R, et al. (2012) Comparison of the efficiency of palladium and silver nanoparticles loaded on activated carbon and zinc oxide nanorods loaded on activated carbon as new adsorbents for removal of Congo red from aqueous solution: Kinetic and isotherm study. Materials Science and Engineering C 32: 725-734.

5. Chauhan N, Pundir CS (2014) Amperometric determination of acetylcholine-A neurotransmitter, bychitosan/gold-coated ferricoxide nanoparticles modified gold electrode. Biosensors and Bioelectronics 61: 1-8.

6. Dadmehr M, Hosseini M, Hani SH, Ganjali MR, Khoobi M, et al. (2014) DNA methylation detection by a novel fluorimetric nanobiosensor for earlycancerdiagnosis. Biosensors and Bioelectronics 60: 35-44.

7. Sahraoui $Y$, Barhoumi H, Maaref A, Nicole JR (2011) A novel Capacitive Biosensor for Urea assay based on Modified Magnetic Nanobeads. Sensors letters 9: 2141-2146.

8. Mobley HLT, Hausinger RP (1989) Microbial ureases: significance, regulation, and molecular characterization. Microbiol. Rev 53: 85-108.

9. Ghaedi M, Montazerozohori M, Mousavi A, Khodadoust S, Mansouri M (2012) Construction of new iodide selective electrodes based on bis(transcinnamaldehyde)1,3-propanediimine(L) zinc(II) chloride [ $\mathrm{ZnLCI} 2]$ and bis(transcinnamaldehyde) 1,3-propanediimine(L) cadmium(II) chloride [CdLCl2]. Materials Science and Engineering C 32: 523-529.

10. Ghaedi M, Naderi S, Montazerozohori M, Sahraei R, Daneshfar A (2012) Modified carbon paste electrodes for $\mathrm{Cu}(\mathrm{II})$ determination. Materials Science and Engineering C 32: 2274-2279.

11. Bellon-Fontaine MN, Mozes N, Van-der-Mei HC, Sjollema J, Cerf O, et al. (1990) A comparison of thermodynamic approaches to predict the adhesion of dairy microorganisms to solid substrata. Cell Biophysics 17: 93-106.

12. Gallardo-Moreno AM, González-Martín ML, Pérez-Giraldo C, Bruque JM, Gómez-García AC (2002) Serum as a factor influencing adhesion of Enterococcus faecalis to glass and silicone. Applied and Environmental Microbiology 68: 5784-5787.

13. Wang J, Huang N, Pan CJ, Kwok SCH, Yang P, et al. (2004) Bacteria repellence from polyethylene terephthalate surface modified by acetylene plasma immersion ion implantation-deposition. Surface Coatings Technology 186: 299-304.
14. Bayoudh S, Othmane A, Bettaieb F, Bakhrouf A, Ben Ouada H (2006) Quantification of the adhesion free energy between bacteria and hydrophobic and hydrophilic substrata. Materials Science and Engineering C 26: 300-305.

15. Marmur A (1994) Thermodynamic aspects of contact angle hysteresis. Adv. Colloid Interface Sci 50: 21-141.

16. Van Oss CJ, Good RJ, Chaudhurg MK (1987) Monopolar surfaces. Advances in Colloid and Interface Science 28: 35-64.

17. Binnig G, Quate CF, Gerber C (1986) Atomic force microscope. Phys. Rev Lett 56: $930-933$

18. Souiri M, Mora-Ponsonnet L, Glinel K, Othmane A, Jouenne T (2009) Surface assembly on biofunctional magnetic nanobeads for the study of protein-ligand interactions, Colloids and Surf B: Biointerfaces 68: 125-129.

19. Braham Y, Barhoumi H, Maaref A, Bakhrouf A, Jaffrezic-Renault N (2013) Modified Insulator Semiconductor Electrode With Functionalized nanoparticles for Proteus Mirabilis Bacteria Biosensor Development, Materials Science and Engineering C 33: 4504-4511.

20. Ederer GM, Jackie HC, Donna JB (1971) Rapid Test for Urease and Phenylalanine Deaminase Production Appl. Microbiology 21: 545.

21. MubarakAli D, Thajuddin N, Jeganathan K, Gunasekaran M (2011) Plant extract mediated synthesis of silver and gold nanoparticles and its antibacterial activity against clinically isolated pathogens, Colloids and Surfaces B: Biointerfaces 85: $360-365$

22. Manos J, Belas R (2006) The genera Proteus, Providencia, and Morganella In The prokaryotes: An evolving electronic resource for the microbiological community, Springer-Verlag 6: 245-269.

23. Laviron E (1979) General expression of the linear potential sweep voltammogram in the case of diffusionless electrochemical systems. Journal of Electroanalytical Chemistry and Interfacial Electrochemistry 101: 19-28.

24. Anderson MR, Evaniak MN, Zhang M (1996) Influence of Solvent on the Interfacial Structure of Self-Assembled Alkanethiol Monolayer. Langmuir 12 2327-2331.

25. Seydel U, Lindner B, Wollenweber HW, Rietschel ET (1984) Structural studies of the lipid $A$ components of enterobacterial lipopolysaccharides by laser desorption mass spectrometry. Location of acyl groups at the lipid A backbone. European Journal of Biochemistry 145: 505-509.

26. Hallab NJ, Bundy KJ, O'Connor K, Moses RL, Jacobs JJ (2001) Evaluation of metallic and polymeric biomaterial surface energy and surface roughness characteristics for directed cell adhesion. Tissue Engineering 7: 55-71.

27. Barhoumi H, Maaref A, Jaffrezic-Renault N (2011) Urea impedimetric biosenso based on modified gold microelectrode with 2-amino-6-purinethiol. Sensors letters 9: 2116-2122.

28. Bouriga S, Hafaid I, Korri-Youssoufi H, Maaref A, Jaffrezic N (2009) A nove urea biosensor based on modified electrodes with urease immobilized on poly(N-hydroxyphtalimide-pyrrole-co-pyrrole) film incorporating ethyl amine ferrocene as redox marker. Sensors Lett 7: 731-738.

Submit your next manuscript and get advantages of OMICS Group submissions

Unique features:

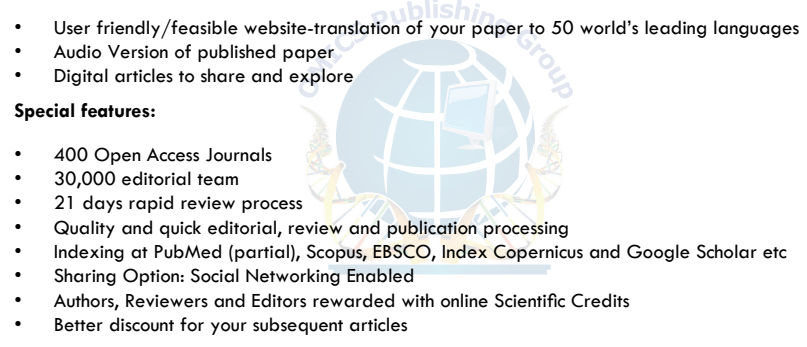

Better discount for your subsequent articles

Submit your manuscript at: http://www.omicsonline.org/submission
Citation: Braham Y, Barhoumi H, Maaref A, Bakhrouf A, Heywang CG, et al. (2015) Characterization of Urea Biosensor Based on the Immobilization of Bacteria Proteus Mirabilis in Interaction with Iron Oxide Nanoparticles on Gold Electrode. J Biosens Bioelectron 6: 160. doi: 10.4172/2155-6210.1000160 